\title{
Giving Banana 'Raja' Peel Extract (Musades Paradisiaca Sapientium) After Moderate Intensity Training Reduces MDA Levels In Rats
}

\author{
Andre Andarianto ${ }^{1}$, Adi Pranoto², Berliana Dwi Nandita Sandy ${ }^{3}$, Rias Gesang \\ Kinanti $^{1}$, Mahmud Yunus ${ }^{1^{*}}$ \\ ${ }^{1}$ Sport Science Department, Faculty of Sport Science State University of Malang \\ ${ }^{2}$ Sport Health Science, Faculty of Medicine Airlangga University \\ ${ }^{3}$ Faculty of Veterinary Medicine, Airlangga University \\ *mahmud.marias@gmail.com
}

\begin{abstract}
Exercise that is done regularly, measured and continuously has a positive impact in reducing levels of malondialdehyde (MDA). MDA is an end product of fat peroxidation that can be used as a biological biomaker to describe the degree of oxidative stress. This study aims to analyze the effect of Raja Banana peel extract (mussa paradisiaca sapientum) on reducing MDA levels in Rattus Norvegicus Strain Wistar rats after moderate and high intensity exercise. The study design was the randomized posttest-only group design, 24 tails, male Rattus Norvegicus Strain Wistar, 8 weeks, $160 \pm 20$ grams and randomly divided into 4 groups. $K_{1}(n=6$, moderate intensity exercise, treadmill with a speed of $14-16 \mathrm{~m} / \mathrm{min}$ for 15-30 minutes), $\mathrm{K}_{2}(\mathrm{n}=6$, moderate intensity exercise + giving Raja Banana peel extract, treadmill with a speed of 14-16 $\mathrm{m} / \mathrm{min}$ for $15-30$ minutes), $\mathrm{K}_{3}$ ( $\mathrm{n}=6$, high intensity exercise, treadmill at a speed of $22-25 \mathrm{~m} / \mathrm{min}$ for $10-20$ minutes) and $\mathrm{K}_{4}(\mathrm{n}=6$, high intensity exercise + giving Raja Banana peel extract, treadmill with a speed of 22-25 $\mathrm{m} / \mathrm{min}$ for 10-20 minutes). The training interventions were conducted at $17.00-21.00$ p.m with a frequency of 7 times/week for 8 weeks. The blood was drawn 12 hours after the last exercise intervention. MDA levels were measured using the Thiobarbituric Acid Reactive substance (TBARs) method. Data analysis techniques was using ANOVA test and LSD post hoc test with the Statistical Package for Social Science (SPSS). Results obtained mean MDA levels at $\mathrm{K}_{1}(291.518 \pm 5.551) \quad \mathrm{ng} / \mathrm{mL}, \quad \mathrm{K}_{2} \quad(255.037 \pm 4.851) \quad \mathrm{ng} / \mathrm{mL}, \quad \mathrm{K}_{3}$ (317.074 \pm 7.006$) \mathrm{ng} / \mathrm{mL}$ and $\mathrm{K}_{4}(274.666 \pm 4.919) \mathrm{ng} / \mathrm{mL}(\mathrm{p}=0.000)$. Based on the results of the study, it is concluded that giving Raja Banana peel extract after moderate and high intensity exercise reduced MDA levels in rats.
\end{abstract}

Keywords: Banana peel extract, MDA levels, moderate intensity exercise, high intensity exercise. 


\section{STRADA Jurnal Ilmiah Kesehatan}

DOI: $10.30994 /$ sjik.v9i2.313

ISSN: 2252-3847 (print); 2614-350X (online)

Vol.9 No.2 November 2020 Page.405-411

\section{BACKGROUND}

Exercise is often associated with increased-oxidative stress (Algul et al., 2018; Huang et al., 2015; Moflehi et al., 2012). Oxidative stress is an imbalance between free radical production and antioxidants (Arsana et al., 2013; Otani, 2011; Giustarini et al., 2009). Oxidative stress conditions are characterized by increased production of Reactive Oxygen Species (ROS) (Esgalhado et al., 2015). Excessive production of ROS and oxidative stress contribute to the development of cellular macromolecular oxidation such as lipids, proteins and DNA which can cause pathogenesis of various degenerative and chronic diseases (Spector, 2000). However, this is not well understood.

Exercise can cause an increase in ROS production and oxidative stress (Sachdev and Davies, 2008). Increased ROS production and free oxidative stress depend on the intensity and dose of exercise that performed (Mrakic-Sposta et al., 2015). High intensity exercise increases ROS production and oxidative stress more than moderate intensity exercise (Vezzoli et al., 2014; Finaud et al., 2007; Bailey et al., 2007). Increased ROS production and oxidative stress in the body correlate with pathogenesis of various degenerative diseases such as hypertension, atherosclerosis, chronic kidney disease (CKD), heart failure (Esgalhado et al., 2015), diabetes mellitus (Bloomer et al., 2006), stroke (Hairrudin and Helianti, 2009), coronary heart disease, aging, cancer (Rosahdi et al., 2013), insulin resistance and metabolic syndrome (Otani, 2011; Giustarini et al., 2009). Therefore, to reduce the risk of illnesses that caused by the effects of increased oxidative stress, it is necessary to have a specific strategy to reduce oxidative stress. Oxidative stress is an imbalance between free radical production and antioxidants (Sandhiutami et al., 2017; Arsana et al., 2013). Methods that can be used to maintain the balance of free radical production with antioxidants through giving Raja Banana peel extract (mussa paradisiaca sapientum) after exercise.

Raja Banana peel extract contains flavonoids and saponins which are effective as scavenger hydroxyl radicals $\left({ }^{*} \mathrm{OH}\right)$ and peroxyl radicals (ROO*) (Lee et al., 2004). Flavonoids (flavonoids-OH) are reported to act as scavenger peroxyl radicals (ROO*) that will be regenerated into $\mathrm{ROOH}$ and act as scavenger hydroxyl radicals $(* \mathrm{OH})$ and regenerated into hydrogen peroxide $(\mathrm{H} 2 \mathrm{O} 2)$. Peroxil radical and hydroxyl radical regeneration compounds are more stable, while phenoxyl radicals formed (flavonoids- ${ }^{*}$ ) become less reactive to carry out the propagation reaction. Phenoxyl radical compounds become inactive due to increased hydroxyl reactivity of flavonoid compounds (Nijveldt et $a l .$, 2001). Flavonoid functions as anti-inflammatory, because flavonoids can inhibit the formation of proinflammatory cytokines such as Tumor Necrosis Factor alpha (TNF- $\alpha$ ), interleukin-6 (IL-6), Interleukin 1 beta (IL-1 $\beta$ ) and interferon- $\gamma$ (IFN- $\gamma$ ) (IFF- $\alpha$ ), interleukin-6 (IL-6), Interleukin 1 beta (IL-1 $\beta$ ) and interferon- $\gamma$ (IFN- $\gamma$ ) (IFN- $\gamma$ ) (Akhlaghi, 2009). Flavonoids can function as chelating agents of $\mathrm{Cu}$ and $\mathrm{Fe}$ metals which act as catalysts in the Fenton reaction. This reaction includes the reaction of changing hydrogen peroxide to $* \mathrm{OH}$. This chelating process will reduce the catalytic activity of $\mathrm{Cu}$ and $\mathrm{Fe}$ metals, thereby reducing the formation of radicals $* \mathrm{OH}$ will automatically reduce the damage process of Deoxyribonucleic Acid (DNA), reduce the process of fat peroxidation (Akhlaghi, 2009) and reduce oxidative stress in terms of decreased levels malondialdehyde (MDA). MDA is an end product of fat peroxidation that can be used as a biological biomaker to describe the degree of oxidative stress (Bhale et al., 2014). Based on the background above, this study aims to analyze the effect of Raja Banana peel extract (mussa paradisiaca sapientum) on reducing MDA levels in Rattus Norvegicus Strain Wistar after moderate and high intensity exercise. 


\section{STRADA Jurnal Ilmiah Kesehatan}

DOI: $10.30994 /$ sjik.v9i2.313

ISSN: 2252-3847 (print); 2614-350X (online)

Vol.9 No.2 November 2020 Page.405-411

\section{METHOD}

The study design was the randomized posttest-only group design, 24 tails, male Rattus Norvegicus StrainWistar, 8 weeks, $160 \pm 20$ grams and randomly divided into 4 groups. $\mathrm{K}_{1}(\mathrm{n}=6$, moderate intensity exercise, treadmill with a speed of $14-16 \mathrm{~m} / \mathrm{min}$ for 15-30 minutes), $K_{2}$ ( $n=6$, moderate intensity exercise + giving Raja Banana peel extract, treadmill with a speed of $14-16 \mathrm{~m} / \mathrm{min}$ for $15-30$ minutes), $\mathrm{K}_{3}(\mathrm{n}=6$, high intensity exercise, treadmill at a speed of $22-25 \mathrm{~m} / \mathrm{min}$ for $10-20$ minutes) and $\mathrm{K}_{4}$ ( $\mathrm{n}=6$, high intensity exercise + giving Raja Banana peel extract, treadmill with a speed of 22-25 $\mathrm{m} / \mathrm{min}$ for 10-20 minutes). All the procedures of the present study were approved by Ethical Committee of Faculty of Medicine, Brawijaya University number 302/EC/KEPK/FKUA/2019.

Moderate intensity exercise was done by rats running on a treadmill with a speed of $14-16 \mathrm{~m} / \mathrm{min}$ for $15-30$ minutes, while high intensity training with a speed of $22-25 \mathrm{~m} / \mathrm{min}$ for 15-30 minutes (Pranoto et al., 2020; Kim et al., 2013). The intervention was carried out at 17.00-20.00 a.m with a frequency of 7 times/week for 8 weeks. Giving Raja Banana peel extract was done 12 hours after moderate and high intensity exercise with a dose of 80 $\mathrm{mg} / \mathrm{kg}$ body weight of experimental animals. Giving Raja Banana peel extract was done by 'sonde'. The blood was drawn from the left ventricle of experimental animals as much as 3 $\mathrm{ml}$. It was carried out 12 hours after the last exercise. MDA levels were measured using the Thiobarbituric Acid Reactive substance (TBARs) method (Esgalhado et al., 2015).

Statistical analysis was using Statistical Packet For Social Science (SPSS) software. The normality test uses the Shapiro-Wilk test. After the data is normally distributed, homogeneity tests are done using the Levene test. After the data were normally distributed and homogeneous, the ANOVA test was performed and continued with the post hoc LSD test with a significance level $(p<0.01)$.

\section{RESULT}

The results of the descriptive analysis of the mean MDA levels can be seen in Table 1 .

Table 1.The Average of MDA Levels in Each Group

\begin{tabular}{ccccc}
\hline Group & n & Mean \pm SD $(\mathbf{n g} / \mathbf{m L})$ & F & $\begin{array}{c}\text { ANOVA } \\
\text { P-Value }\end{array}$ \\
\hline $\mathrm{K}_{1}$ & 6 & $291.518 \pm 5.551$ & & \\
$\mathrm{~K}_{2}$ & 6 & $255.037 \pm 4.851$ & 130.046 & 0.000 \\
$\mathrm{~K}_{3}$ & 6 & $317.074 \pm 7.006$ & & \\
$\mathrm{~K}_{4}$ & 6 & $274.666 \pm 4.919$ & & \\
\hline
\end{tabular}

Based on Table 1 shows that the average MDA levels in $\mathrm{K}_{2}$ is lower compared to $\mathrm{K}_{1}, \mathrm{~K}_{3}$ and $\mathrm{K}_{4}$. Based on the ANOVA test, there is a significant difference in the mean MDA level $(\mathrm{p}=0.000)$. Based on the post hoc LSD test, there are significant differences in MDA levels between $\mathrm{K}_{2}$ and $\mathrm{K}_{1}(\mathrm{p}=0.000), \mathrm{K}_{2}$ with $\mathrm{K}_{3}(\mathrm{p}=0.000), \mathrm{K}_{2}$ with $\mathrm{K}_{4}(\mathrm{p}=0.000), \mathrm{K}_{1}$ with $\mathrm{K}_{3}$ $(\mathrm{p}=0.000), \mathrm{K}_{1}$ with $\mathrm{K}_{4}(\mathrm{p}=0.000), \mathrm{K}_{3}$ with $\mathrm{K}_{4}(\mathrm{p}=0.000)$.

\section{DISCUSSION}

This study aims to analyse giving Raja Banana skin extract (mussa paradisiaca sapientum) to reduce MDA levels in Rattus Norvegicus Strain Wistar rats after moderate and high intensity exercise. Based on the results of the study showed that the average level of MDA in $K_{2}$ is lower compared to $K_{1}, K_{3}$ and $K_{4}$. Based on the ANOVA test, there is a significant difference in the mean MDA level $(\mathrm{p}=0.000)$. These results are in line with the 


\section{STRADA Jurnal Ilmiah Kesehatan}

DOI: $10.30994 /$ sjik.v9i2.313

ISSN: 2252-3847 (print); 2614-350X (online)

Vol.9 No.2 November 2020 Page.405-411

results of research conducted by Sandhiutami et al. (2017) concluded that papaya seed ethanol extract containing flavonoids (antioxidants) significantly reduced MDA levels in rats. Likewise in research conducted by Yuliati et al. (2019) concluded that administration of macassar fruit extract (brucei javanica) significantly reduced MDA levels in rats. The decrease in MDA levels in $\mathrm{K}_{2}$ is probably caused by giving Raja Banana peel extract (mussa paradisiaca sapientum). The content contained in peel extracts, such as flavonoids and saponins, are effective as scavenger hydroxyl radicals $(* \mathrm{OH})$ and peroxyl radicals (ROO*) (Lee et al., 2004). Flavonoids (flavonoids-OH) are reported to act as scavenger peroxyl radicals $\left(\mathrm{ROO}^{*}\right)$ that will be regenerated into $\mathrm{ROOH}$ and act as scavenger hydroxyl radicals $(* \mathrm{OH})$ and regenerated into hydrogen peroxide $(\mathrm{H} 2 \mathrm{O} 2)$. Peroxil radical and hydroxyl radical regeneration compounds are more stable, while phenoxyl radicals formed (flavonoids- $\mathrm{O}^{*}$ ) become less reactive to carry out the propagation reaction. Phenoxyl radical compounds become inactive due to increased hydroxyl reactivity of flavonoid compounds (Nijveldt et al., 2001). Flavonoid functions as anti-inflammatory, because flavonoids can inhibit the formation of proinflammatory cytokines such as Tumor Necrosis Factor alpha (TNF- $\alpha$ ), interleukin-6 (IL-6), Interleukin 1 beta (IL-1 $\beta$ ) and interferon- $\gamma$ (IFN- $\gamma)$ (IFF- $\alpha)$, interleukin-6 (IL-6), Interleukin 1 beta (IL-1 $\beta$ ) and interferon- $\gamma($ IFN- $\gamma$ ) (IFN- $\gamma$ ) Akhlaghi, 2009). Flavonoids can function as chelating agents of $\mathrm{Cu}$ and $\mathrm{Fe}$ metals which act as catalysts in the Fenton reaction. This reaction includes the reaction of changing hydrogen peroxide to $* \mathrm{OH}$. This chelating process will reduce the catalytic activity of $\mathrm{Cu}$ and $\mathrm{Fe}$ metals, thereby reducing the formation of $* \mathrm{OH}$ radicals and will automatically reduce the process of deoxyribonucleic acid (DNA) damage, reduce the process of fat peroxidation (Akhlaghi, 2009) and reduce oxidative stress reviewed from decreased levels MDA.

Exercise can cause an increase in free radical production (Sachdev and Davies, 2008). Increased free radical production depends on the intensity and dose of exercise that is done (Mrakic-Sposta et al., 2015). High-intensity exercise increases free radical production more than moderate-intensity exercise (Vezzoli et al. 2014; Finaud et al., 2007; Bailey et al., 2007). Based on the results of the study showed that the average level of MDA in high intensity exercise is higher than moderate intensity exercise. These results are in line with the results of research conducted by Moflehi et al. (2012) concluded that MDA levels in high intensity exercise were higher than moderate intensity exercise. High levels of MDA in high intensity exercise are likely because during exercise the oxygen demand increases 10 to 20 times and the oxygen to the muscles increases 100 to 200 times (Candrawati, 2013; Sen, 1995). When oxidative phosphorylation is in the mitochondria, oxygen is reduced by the mitochondrial electron transport system for the formation of adenosine triphosphate (ATP) and water (H2O) (Mrakic-Sposta et al., 2015). In oxidative phosphorylation (electron transport) as much as $2-5 \%$ of the total oxygen demand can be converted into free radicals so as to produce ROS (Anita, 2014; Arsana et al., 2013). In addition, a training that done with heavy intensity and wrong dosage can increase the production of reactive oxygen species (ROS), reduce antioxidants and increase oxidative stress. Increased ROS production and decreased antioxidant production can increase lipid peroxidation which has an impact on increasing MDA production (Pingitore, 2015).

\section{CONCLUSION}

Based on the results of the study it is concluded that giving Raja Banana peel extract after moderate and high intensity exercise reduces MDA levels in rats. Giving Raja Banana peel extract at a dose of $80 \mathrm{mg} / \mathrm{kg}$ body weight post moderate intensity exercise 


\section{STRADA Jurnal Ilmiah Kesehatan}

DOI: $10.30994 /$ sjik.v9i2.313

ISSN: 2252-3847 (print); 2614-350X (online)

Vol.9 No.2 November 2020 Page.405-411

performed 7 times/week for 8 weeks is more effective in reducing MDA levels compared to moderate intensity exercise and high intensity exercise without giving Raja Banana peel extract.

\section{REFERENCES}

Akhlaghi, M., Brian, B. 2009. Mechanisms Of Flavonoid Protection Against Myocardial Ischemia-Reperfusion Injury. Journal of Molecular and Cellular Cardiology, 46(3): 309-317. https://doi.org/10.1016/j.yjmcc.2008.12.003.

Algul, S., Ugras, S. and Kara, M. 2018. Comparative evaluation of MDA levels during aerobic exercise in young trained and sedentary male subjects. East J Med, 23(2): 98-101. https://doi.org/10.5505/ejm.2018.40469.

Anita, D.C. 2014. Kadar Glukosa Darah dan Malondialdehid Ginjal Tikus Diabetes yang Diberi Latihan Fisik. Muhammadiyah Journal of Nursing, 1(2): 109-116.

Arsana, I.N., Adiputra, N., Pangkahila, J.A. and Putra-Manuaba, I.B. 2013. Garcinia Mangostana L.Rind Extract And Physical Training Reduce Oxidative Stress In Wistar Rats During Maximal Physical Activity. Indonesian Journal of Biomedical Sciences, 7(2): 63-68.

Bailey D.A., Lawrenson L., McEneny J., Young, I.S., James, P.E., Jackson, S.K., Henry, R.R., Mathieu-Costello, O., McCord, J.M. and Richardson, R.S. 2007. Electron paramagnetic spectroscopic evidence of exercise-induced free radical accumulation in human skeletal muscle. Free Radical Research, 41(2): 182-190. https://doi.org/10.1080/10715760601028867.

Bhale, D. V., Patil, D.S. and Mahat, R.K. Study of Malondialdehyde (MDA) As a Marker of Oxidative Stress in Obese Male Individuals. International Journal of Recent Trends in Science and Technology, 10(1): 51-52. https://www.researchgate.net/publication/313895349.

Bloomer, R.J., Goldfarb, A.H. and Mckenzie, M.J. 2006. Oxidative Stress Response toAerobic Exercise: Comparison ofAntioxidant Supplements. Medicine \& Science In Sports \& Exercise, 38(6): 1098-1105. https://doi.org/10.1249/01.mss.0000222839.51144.3e.

Candrawati, S. 2013. Pengaruh Aktivitas Fisik terhadap Stres Oksidatif. Jurnal Mandala of Health, 6(1): 454-461.

Esgalhado, M., Stockler-Pinto, M.B., de França Cardozo, L.F.M., Costa, C., Barboza, J.E. and Mafra, D. 2015. Effect of acute intradialytic strength physical exercise on oxidative stress and inflammatory responses in hemodialysis patients. Kidney Res Clin Pract, 34(1): 35-40. http://dx.doi.org/10.1016/j.krcp.2015.02.004.

Finaud, J., Lac, G. and Filaire, E. 2007. Oxidative stress: relationship with exercise and training. Sports Medicine, 36(4): 327-358. https://doi.org/10.2165/00007256-200636040$\underline{00004 .}$

Giustarini, D., Dalle-Donne, I., Tsikas, D. and Rossi, R. 2009. Oxidative stress and human diseases: Origin, link, measurement, mechanisms, and biomarkers. Crit Rev Clin Lab Sci, 46(5-6):241-281. https://doi.org/10.3109/10408360903142326.

Hairrudin and Helianti, D. 2009. Efek Protektif Propolis Dalam Mencegah Stres Oksidatif Akibat Aktifitas Fisik Berat (Swimming Stress) 'Propolis' Protective Effect to Prevent Oxidative Stress Caused by Strenous Physical Activity (Swimming Stress). Jurnal Ilmu Dasar, 10(2): 207-211.

Huang, C-J., McAllister, M.J., Slusher, A.L., Webb, H.E., Mock, T. and Acevedo, E.O. 2015. Obesity-Related Oxidative Stress: the Impact of Physical Activity and Diet 


\section{STRADA Jurnal Ilmiah Kesehatan}

DOI: $10.30994 /$ sjik.v9i2.313

ISSN: 2252-3847 (print); 2614-350X (online)

Vol.9 No.2 November 2020 Page.405-411

Manipulation. Sports Medicine - $\quad$ Open, 1(32): 1-12. https://doi.org/10.1186/s40798-015-0031-y.

Kim, D.H., Kim, S.H., Kim, W.H. and Moon, C.R.2013. The effects of treadmill exercise on expression of UCP-2 of brown adipose tissue and TNF- $\alpha$ of soleus muscle in obese Zucker rats. Journal of Exercise Nutrition and Biochemistry 17(4): 199-207. https://doi.org/10.5717/jenb.2013.17.4.199.

Lee, J., Koo, N. and Min, D.B. 2004. Reactive Oxygen Species, Aging, And Antioxidative Nutraceuticals. Compre Rev. in Food Sci. and Food Safety. 3: 21-33.

Moflehi, D., Kok, L.Y., T-K, T.F and Amri, S. 2012. Effect of Single-Session Aerobic Exercise with Varying Intensities on Lipid Peroxidation and Muscle-Damage Markers in Sedentary Males. Global Journal of Health Science, 4(4): 48-54. https://doi.org/10.5539/gjhs.v4n4p48.

Mrakic-Sposta, S., Gussoni, M., Porcelli, S., Pugliese, L., Pavie, G., Bellistri, G., Montorsi, M., Tacchini, P. and Vezzoli, A. 2015. Training Effect on Production Determined by Electron Paramagnetic Resonance in Master Swimmers. Oxidative Medicine and Cellular Longevity, 2015: 804794https://doi.org/10.1155/2015/804794.

Nijveldt, R.J., van Nood, E., van Hoorn, D.E., Boelens, P.G., van Norren, K., van Leeuwen, P.A. 2001. Flavonoids: A Review Of Probable Mechanism Of Action And Potential Applications. Am. J. Clin. Nutr. 74(4): 418-25. https://doi.org/10.1093/ajen/74.4.418.

Otani, H. 2011. Oxidative stress as pathogenesis of cardiovascular risk associated with metabolic syndrome. Antioxid Redox Signal, 15(7):1911-1926. https://doi.org/10.1089/ars.2010.3739.

Pingitore, A., Lima, G.P.P., Mastorchi, F., Quinones, A., Iervasi, G. and Vassalle, C. 2015. Exercise and Oxidative Stress: Potential Effect of Antioxidant Dietary Strategies in Sport. Journal Nutrition, 31(7-8): 916-922. https://doi.org/10.1016/j.nut.2015.02.005.

Pranoto, A., Wahyudi, E., Prasetya, R.E., Fauziyah, S., Kinanti, R.G., Sugiharto and Rejeki, P.S. 2020. High intensity exercise increases brain derived neurotrophic factor expression and number of hippocampal neurons in rats. Comparative Exercise Physiology, 1-8. https://doi.org/10.3920/CEP190063.

Rosahdi, T.D., Kusmiyati, M. and Wijayanti, F.R. 2013. Uji Aktivitas Daya Antioksidan Buah Rambutan Rapiah Dengan Metode DPPH. Jurnal Istek, 7(1): 1-15.

Sachdev S. and Davies K.J.A. 2008. Production, detection, and adaptive responses to free radicals in exercise. Free Radical Biology \& Medicine, 44(2): 215-223. https://doi.org/10.1016/j.freeradbiomed.2007.07.019.

Sandhiutami, N. M. D., Desmiaty, Y., \& Anbar, A. 2017. Efek Antioksidan Ekstrak Etanol Biji Pepaya (Carica papaya L.) terhadap Aktivitas Enzim Superoksida Dismutase dan Kadar Malondialdehid pada Mencit Stress Oksidatif dengan Perenangan. Jurnal Ilmu Kefarmasian Indonesia, 14(1): 26-32.

Sen, C.K. 1995. Oxidants and antioxidants in exercise. Journal of Applied Physiology, 79(3): 675-686.

Spector, A. 2000. Review: Oxidative stress and disease. J Ocul Pharmacol Ther, 16(2):193-201. https://doi.org/10.1089/jop.2000.16.193.

Vezzoli A., Pugliese L., Marzorati M., Serpiello F. R., La Torre A. and Porcelli S. Time-course changes of oxidative stress response to high-intensity discontinuous training versus 


\section{STRADA Jurnal Ilmiah Kesehatan}

DOI: $10.30994 /$ sjik.v9i2.313

ISSN: 2252-3847 (print); 2614-350X (online)

Vol.9 No.2 November 2020 Page.405-411

moderate-intensity continuous training in masters runners. PLOS ONE, 9(1): e87506 https://doi.org/10.1371/journal.pone.0087506.e87506.

Yuliati, M.E.P., Aman, I.G.M. and Dewi, N.N.A. 2019. Macassar fruit extract (Brucea javanica (1.) merr) increased the level of superoxide dismutase (SOD) but had no effect on the level of malondialdehyde (MDA) in paraquat-treated male swiss Webster mice. Indonesian Journal of Anti-Aging Medicine, 3(2): 29-32. 